\title{
Research of Path of the Intangible Cultural Heritage Protection in Sports Field in Northern Shaanxi
}

\author{
Xiaofeng JIANG \\ Yan'an University \\ Yan'an , 716000 China
}

\begin{abstract}
Through relevant theories of the sport Intangible Cultural Heritage, concepts analysis to the sports field in northern Shaanxi intangible cultural heritage protection as a case study, combined with the results of the basis of previous folklore, folk culture, traditional culture of sports and cultural studies, we analyze the status quo of China's sports and the construction of non-material cultural heritage of development problems and propose constructive thinking and countermeasures: We should overcome the negative impact of anti-culture, pseudo-folk and other phenomena in the sports category of intangible cultural heritage protection, with the actual specific factors, retain the essential attribute of sports. Irrational thoughts should calmly protection exist, to grasp the fundamental purpose and core of the problem. The protection of intangible cultural heritage sports need appropriate national and local policies to follow up. We should stop blindly follow the trend in protection work, and establish the right culture mentality.
\end{abstract}

Keywords- Sports intangible cultural heritage; protection; northern Shaanxi domain

\section{INTRODUCTION}

Oral and Intangible Cultural Heritage is a project for the protection of intangible cultural heritage established by UNESCO, known as intangible heritage. It is dependent on the personal presence of a non-material form of word of mouth heritage body. Intangible Cultural Heritage of the word began to emerge in recent years. In recent years, all of the reference to UNESCO's intangible cultural heritage was originally called "the protection of folk culture and traditional culture", with the protection of intangible cultural heritage, the rise of the tide, in November in 1989, the UNESCO adopted the "traditional culture and folklore protection initiative" in the field of protection of intangible cultural heritage has taken the first step. Although it is for a limited range, it is the first formal official documents of international non-material cultural heritage protection areas, including the definition of the relevant concepts and united to protect a series of initiatives to protect the recommendations for future the main tone of action set and directly affect our current definition of intangible cultural heritage. After 1989, this initiative proposes that, from 1995, UNESCO will officially take it as a standard, sub-regional, intangible cultural heritage of the census work in stages, and finally in 1999 the census results in all regions summary of the investigation report made worldwide. Based on the same idea, in November in 1997, UNESCO held its 29th plenary session, which adopted a resolution on the establishment of an international identification. Accordingly, at its 154th meeting, the UNESCO Executive Board pointed out that the "oral heritage" and "intangible heritage" are inseparable, so in the future, to identify in the back, "oral heritage" will be added and "non-material" is defined. Then, at the 155th meeting of the Board, the UNESCO declared on the assessment rules of the Oral and Intangible Heritage of outstanding works. Subsequently, the UNESCO in June in 2000 formally established "a masterpiece of the Oral and Intangible Cultural Heritage List" project, in May 2001 announced the first shortlist. At the 32nd General Assembly of UNESCO sector in October 2003, they held on by the "Safeguarding of the Intangible Cultural Heritage", China join the "Convention" in 2004 formally approved by the Standing Committee of the National People, a join "the Convention" One of the country earlier.

According to "Safeguarding of the Intangible Cultural Heritage" by UNESCO in Paris in the definition, it "refers to the various communities, groups and, sometimes, individuals are recognized as part of their cultural heritage of various social practices, the concept of expression, performance form of knowledge, skills and tools related objects, artefacts and cultural spaces. Intangible Cultural Heritage by humans orally or action mode are legend, a national historical heritage and extensive, prominent representative of the folk cultural heritage. It has been regarded as history and culture of the "living fossil", "national memory back." And in accordance with the provisions of the Convention on the non-material cultural heritage, after the official implementation of the Convention, this heritage unified renamed the "intangible cultural heritage."

\section{THE ENDANGERED INTANGIBLE CULTURAL HERITAGE IN SPORTS FIELD IN NORTHERN SHAANXI}

Sports field in northern Shaanxi non-material cultural heritage endangered status can be divided into five categories. The first category, inheritors fault phenomenon: some quite accomplished main inheritors phased out due to advanced age, and some have died, and now as for the young players, less prestige, level of staff training and participation leads to phenomenon that people alternately fault many heritage projects; second class, lifestyle changes: many young people and even some master the skills of artists forced to live outside the home, business, and other lifestyle instead of relying on the phenomenon previously mastered skills to survive. The third category, it is influenced by modern culture shock: With the advancement of society, market economy and the impact of increasingly rich cultural life of the masses, television and the popularity of the Internet, people are increasingly indifferent interested in the arts and gradually improve the aesthetic taste and cultural life has become increasingly rich and diverse, which increasingly 
weakened because of traditional folk, traditional festivals and cultural atmosphere of increasingly mediocre. People ran donkey Jingbian, Hengshan old drum, Yishan drum, Jingbian LUOCHUAN limp drum, Hengshan old drum, Yishandrum, LUOCHUAN limp drums, dry state conversion dragon, red fist, Mountain Tai Chi sword hanging station Shehuo interest reduction, resulting in a weak mass base of these projects. The fourth class, poor integration of the society: A single point of Ansai drum action leads to simplification. The ancient art combines with the spirit of the times incomplete without depth of modern ideals, such as embodied spirit inadequate; fifth, it lost its original habitat. For example, the situation that martial arts in rural areas, such asred boxing, were popular in the past no longer exists in vogue. It is also dwindling in the vast rural areas of the display platform. As to Yang County, due to the intensification of modernization, some local community changed XuantaiShehuointo a large truck or tractor carrying. Huaimu Liangjia in some local community is gradually being replaced by steel iron bars, greatly reducing its original ecological quaint mean. Everyone is carrying shoulder dozens of magnificent shocking the audience and lift the soul united by the spirit of unity and cooperation greatly weakened or disappeared, reducing the humanities content. All these reasons the sports field in northern Shaanxi endangered intangible cultural heritage.

\section{NECESSITY OF PROTECTION OF INTANGIBLE CUlTURAL HERITAGE IN SPORTS}

As an important part of the cultural heritage of mankind, sports intangible cultural heritage has played an important role in the evolution of human civilization. We can even see national sports development from the trackand the continuous progress of human civilization, the conflict, the integration of the scene. But national sports events in the world have been more or less impact with strong Western sports culture. How to deal with the protection and development of Western sports and ethnic relations between traditional sports and national traditional sports? It becomes a thorny issue before us.

\section{A. Intangible Cultural Heritage Protection and Inheritance is a Necessary Requirement Process of Human Civilization}

Either excellent traditional culture or civilization is spiritual nourishment of advanced modern humans. Ours is a long history of civilization, not only has a lot of intangible cultural heritage, but also has a wealth of intangible cultural heritage. These non-material cultural heritage protections are a continuation of the history of national publicity, emotional intelligence links and extend the era of thinking to enhance the social style, favorable way to cultivate public accomplishment. In a letter to Chinese President $\mathrm{Hu}$ Jintao as the 28th meeting of UNESCO's World Heritage Committee congratulatory message stated: Strengthening the World Heritage has become an urgent task of the international community. This is a noble history, which has given us the responsibility to achieve the necessary requirements for the continuation of human civilization and sustainable development.

\section{B. Safeguarding of the Intangible Cultural Heritage Is an Important Safeguard to Ensure the World's Cultural Diversity}

Culture has a variety of different forms at different times and different places. This manifestation of human diversity shows various ethnic groups and various social characteristics of uniqueness and diversity. Future world peace can only be built on the foundation of civilization pluralistic system side by side on. Because harmony is only achieved on the basis of diversity, it is the real harmony. Only in the countries of Eastern and Western civilization system and major premise of independence and equal dialogue consistency under implementation, it is the real humane consistency. Protection of traditional culture of each nation of the world is the consensus of the world and the general requirements for all ethnic groups. As pointed out by UNESCO: we should respect for cultural diversity, tolerance, dialogue and cooperation is one of the best guarantees of international peace and security. As the national traditional sports culture plays an important part of the national culture, it should also be put on the protection of the agenda.

\section{MEASURES OF InTANGIBLE CUltural HERITAGE} PROTECTION IN SPORTS FIELD IN NORTHERN SHAANXI

\section{A. To Increase the Popularity of Efforts andEnhance Awareness of Civil Protection}

To further strengthen the protection of our cultural heritage, the State Council sets the second Saturday in June each year as China's "Cultural Heritage Day" from 2006. This indicates that China's cultural heritage protection work has entered a new historical stage. Country set up a "Cultural Heritage Day", which is to the whole society outreach knowledge of cultural heritage protection, in the whole society to protect the cultural heritage of a favorable environment for sports and public opinion atmosphere. We can rely on the network, media publicity showcase of intangible cultural heritage, holding various forms of intangible cultural heritage exhibition activities, concessions open various cultural attractions, thereby enhancing awareness of the whole society on the traditional culture of the Central Plains. We should improve public Intangible awareness of cultural heritage protection and promote the protection of intangible cultural heritage.

\section{B. To Make Full Use of the Effectiveness of Government Functions}

To give full play to the role of government in the protection of intangible cultural heritage, it should do something. Government should fully organize all kinds of government-led intangible folk cultural heritage resources, under the mode of public participation, good for the "nonleft" in the spirit and analysis and digging of essence. Second, governments need to provide institutional support. Because China's "non-left" protection has just started, all aspects of the laws and regulations need to be constantly updated. 
Especially non-material cultural heritage protection legislation sports needs to improve. This requires government's careful research and legislation and making policy of Intangible Cultural Heritage protection. Then, it comes to financial support. It is reported that the province will be relevant provincial projects, and part of the national heritage project representative, representative successors have support and subsidies to encourage the city and county for municipal, county and heritage projects to support and encourage people, to make "non-left" as soon as possible to protect heritage standardized and scientific.

\section{To Rely on School Resources and Play Educational Advantages}

As the propagation of traditional culture, school education establishments have comprehensive human resources and material resources and a unique advantage in terms of inheritance and protection of intangible cultural heritage. Students are fully capable of the obligation to become the subject of various types of intangible cultural heritage. Government with the school "non-left" protect has a variety of ways of cooperation by creating various types of intangible cultural heritage exhibition hall, social heritage base, carry out "Shaolin boxing into the classroom" and other related activities, both to protect the heritage of various kinds of "non- left "resources and enrich the classroom life. Meanwhile,according to their actual situation, universities set the "non-left" to protect the relevant professional, cultural heritage protection personnel training. Itis the case that Henan University applied for field training base of Cultural Reform and Development in northern Shaanxi.

\section{To Protect Heritage by Industrialized Operation of the Market}

"Protection and rescue first, rational use, heritage and development" is the working principle of national intangible cultural heritage. The road of development of Shaolin martial arts are lessons to other sports Intangible Cultural Heritage reference. The main advantage of the development of Shaolin kungfu to the "economy of effort" on the road, through a series of market-oriented operation performances, organizing various competitions and fitness activities is to return it to its existence and development of civil society, improve their own influence, meet the internal demand of contemporary people, make a good inheritance and development of the essence of Shaolin martial arts, and gradually form a Shaolin martial arts-based industries. But we need a clear understanding of industrialization sports "Intangible Cultural Heritage" project, we should maintain a distinctive ethnic characteristics basis, to meet the public and we must not give up the essence of their own culture, its head was not worth the candle.

\section{E. To Strengthen the Long-term Protection of Intangible Cultural Heritage in Sports}

Planning and Management Sports Protection of Intangible Cultural Heritage is not new, but it needs a long- term process. Therefore, in the development of specific conservation strategies to be holistic, overall planning must be for the protection and protection, which should give priority to intangible cultural heritage imminent demise, instead of allowing local declaration. Followed by the need to consider the current situation of older people generally too large inheritance, and to strengthen the inheritors of team building, team building should have a reasonable age interval. Again they need to assess the existing feedback mechanisms to improve, so that the "non-left" project protection, inheritance, use, develop mechanisms combine to promote each other.

Heritage protection of intangible cultural heritage is a historic era of mutual tolerance and issues. Although the protection of intangible cultural heritage of our province's sports take the appropriate measures and achieved some success. But you should see the sports intangible cultural heritage protection work and long-term persistence.

\section{CONCLUSIONS}

Treasure, protection, inheritance of humanity's cultural heritage is to have a better future development. As an important part, sports Cultural Heritage also have the same irreplaceable role. We should protect and make good use of the intangible cultural heritage, to inherit and carry forward national cultural traditions, promote national unity and safeguard national unity, self-confidence and enhance national cohesion. Promoting socialist spiritual civilization has important and far-reaching significance.

\section{ACKNOWLEDGEMENT}

Project topics: Shaanxi Provincial Department of Education issues, Shaanxi Province Sports Protection of nonmaterial cultural heritage, numbers, 12JK0236

Project topics: Yan'an City Association of Social issues, research and development in the transformation of traditional sports in northern Shaanxi Intangible cultural horizons, numbers, 14CWY35

\section{REFERENCES}

[1] Ma Zengqiang, Julie.Research of Intangible Cultural Heritagein Sports Protection - Taking Shaanxi Province for Example [J]. Xi'an Institute of Physical Education, 2011,02: 139-142 + 155 .

[2] Yu Kuilong.Status Analysis of Sports Intangible Cultural Heritage Protection in Shaanxi Province [J].Yichun University, 2011,12: 169171.

[3] Zhang Zhuping.Research of Intangible Cultural Heritage in Sports Protection - Taking Henan Province for Example [J]. Contemporary Sports Science, 2012,01: 1-2 + 4 .

[4] Zhang Yuqiang, Chen Youzhong.Research Review of Traditional Sports Intangible Cultural Heritage Protection [J].Hebei Institute of Physical Education, 2012,05: 86-90.

[5] Zhang Xiancheng, Su Xiuyan, Yang Kai.Research of Rural Sports Tourism and Sports Intangible Cultural Heritage Protection of New Rural Construction Development [J]. Shandong Institute of Physical Education, 2010,01: 18-23 + 27.

[6] GuoPengfei.Research of Henan Sports Intangible Cultural HeritageProtection [J]. Shaolin and Taiji (Plains Sports), 2010,11: 3235. 